\title{
Acute and sub-chronic toxicity studies of the ethanol extract of the leaves of Sphenocentrum jollyanum (Menispermaceae)
}

\author{
${ }^{1 *}$ Mbaka G. O., ${ }^{2}$ Adeyemi 0.0 and ${ }^{3}$ Oremosu A. A. \\ $1^{1 *}$ Department of Anatomy, Olabisi Onabanjo University, Remo Campus, Ogun State, Nigeria. \\ ${ }^{2}$ Department of Pharmacology, College of medicine of the University of Lagos, Idi Araba, \\ Lagos, Nigeria. \\ ${ }^{3}$ Department of Anatomy, College of Medicine of the University of Lagos, Idi-Araba, Lagos, \\ Nigeria. \\ "Corresponding Author, G.O. Mbaka, E-mail: mbaaka@yahoo.com \\ GSM: 234-805-8426729 \\ ABSTRACT
}

\begin{abstract}
The acute toxicity study of the leaves of Sphenocentrum jollyanum (SJ) showed no toxicity when administered up to $11 \mathrm{~g} / \mathrm{kg}$ body weight orally while intra-peritoneal (IP) administration produced dose dependent mortality with median acute toxicity $\left(\mathrm{LD}_{50}\right)$ of $1445.4 \mathrm{mg} / \mathrm{kg}$. In sub-chronic study, the extract administered for a period of 120 days showed no mortality or morbidity. There was significant weight gain in both treated and control groups while gross examination of internal organs revealed no detectable inflammation. The blood glucose and total cholesterol levels demonstrated dose dependent decrease while high density lipoprotein cholesterol (HDLcholesterol) increased with dose. In the liver function test, there were no significant $(p>0.05)$ changes in alanine amino transferase (ALT) and aspertate amino transferase (AST) in the extract treated animals. The renal function profile, serum creatinine and urea levels were not significantly altered compared to the control. In haematological evaluation, significant increase $(p<0.05)$ in red blood cells (RBC), packed cell volume (PCV) and haemoglobin $(\mathrm{Hb})$ were observed in the treated animals compared to the control while mean corpuscular (MCV), mean corpuscular haemoglobin $(\mathrm{MCH})$, mean corpuscular haemoglobin concentration (MCHC) and white blood cells (WBC) showed no significant changes. The result therefore suggests that the leaves extract was potentially safe for consumption orally even at chronic administration.
\end{abstract}

Key words: Sphenocentrum jollyanum, leaves, acute and sub-chronic toxicities

\section{INTRODUCTION}

The use of medicinal plant as a therapy for disease condition is an age long practice. In regions with rich diversity of flora spread, it forms an important component of their natural wealth. Herbs and herbal formulations for the treatment of ailments have continued to receive increased attention because of the strong belief that these products are safe (Farnsworth and Soejarto, 1985; Said et al., 2002). This assumption to a large extent may have influenced the indiscriminate use of these formulations by many, particularly amongst the rural populace. The incidence of adverse effects and sometimes life-threatening conditions allegedly emanating from these herbal medicines has been reported among various ethnic groups (Elvin-Lewis, 2001; Chan, 2003). Consequently, it has become imperative to ascertain the toxicity profile of these medicinal herbs.

Sphenocentrum jollyanum Pierre (Menispermaceae) is a perennial plant that grows naturally along the west coast sub region of Africa with expanse from Cameroon across Nigeria to Sierra Leone. The leaf is up to $20 \mathrm{~cm}$ in length with the breadth of $5-12 \mathrm{~cm}$ (Nia et al., 2004). SJ has been shown to display a wide spectrum of biological and pharmacological activities. Its medicinal importance was first reported by Dalziel (1955) in which it was noted that the leaves decoctions were used as vermifuge. It is reputed for use in dressing wounds particularly chronic wounds, feverish conditions, cough as well as being an aphrodisiac (Dalziel, 1955; Iwu, 1993). The plant is also used for treating jaundice, breast engorgement related to the menstrual cycle, tumours and inflammatory conditions (Iwu, 1993; Odugbemi, 2006). According to studies (Iwu, 1993; Nia et al., 2004), the leaves of the plant possess significant anti-inflammatory, anti-angiogenic and analgesic properties. They have also been found to be potent against polio type-2 virus (Moody et al., 2006). 
Although the leaves of SJ are used for various purposes, to our knowledge no literature exists on its toxicity profile. This study was therefore designed to evaluate the acute and chronic toxicity of the ethanolic leaf extract of SJ.

\section{MATERIAL AND METHODS}

Plant materials: Fresh aerial part of SJ growing in the wild was collected from a farm land in Oru-ljebu and authenticated by a taxonomist, Dr. O. A. Ugbogu, Chief Research Officer at the Forest Research Institute of Nigeria (FRIN) where voucher specimen of the plant has been deposited in the herbarium (FHI/108203).

Extract preparation: The fresh leaves were dried in an oven regulated at $40{ }^{\circ} \mathrm{C}$. The dried leaves were reducted to a coarse powder $(567 \mathrm{~g})$ with an electric grinder and extracted in three batches. Each was placed in a Soxhlet extractor and extracted with absolute alcohol in three cycles for about 46h. The extracted material was filtered with Whatman filter paper No. 4. The filtrate obtained was dried in vacuo between $35-40{ }^{\circ} \mathrm{C}$. The yield $36.7 \mathrm{gm}$ was stored in a refrigerator $\left(4^{\circ} \mathrm{C}\right)$ till it was needed.

Animals: Healthy adult male albino rats weighing between 145-160 $\mathrm{g}$ were obtained from the Laboratory Animal Centre of the College of Medicine of the University of Lagos, Lagos, Nigeria. Having certified their health conditions, they were housed in polypropylene cages at room temperature $(21 \pm 2.8$ ${ }^{0} \mathrm{C}$ ) with $12 \mathrm{~h}$ dark and $12 \mathrm{~h}$ light circle. They were fed standard rodent chow from Livestock Feeds PLC, Lagos and water ad libitum. The use of the animals and the experimental protocol was approved by the Experimental Ethics Committee on Animals Use of the College of Medicine, University of Lagos, Nigeria.

Acute toxicity test: Mice were fasted for $14 \mathrm{~h}$ before the administration of the leaf extract up to $11 \mathrm{~g} / \mathrm{kg}$ orally. Another group of mice fasted for 14 hours were administered with SJ intraperitoneally in graded doses until $100 \%$ mortality was recorded. The group received ethanol leaf extract within the range of 250$4000 \mathrm{mg} / \mathrm{kg}$. The control group was given Tween 80 solution $(10 \mathrm{ml} / \mathrm{kg})$ orally. The animals were observed closely for general toxicity signs and behavioural changes for the first 6 hours and mortality recorded within $24 \mathrm{~h}$. $L D_{50}$ was calculated using the method of Horn (Horn, 1956). .

Chronic toxicity tests: A total of 24 male rats were randomly allotted to the control and the extract treated groups. The doses used were 50, 100 and $200 \mathrm{mg} / \mathrm{kg}$ of the extract dispersed with $2 \%$ Tween
80 solution. The doses were administered orally daily for a period of 120 days. The animal were observed closely for any behavioural changes, body weight changes and mortality and were later sacrificed for internal macroscopic, haematological and biochemical investigations.

Effects on vital organs: Following the sacrifice, qualitative data on the weights of vital organs (heart, lungs, liver, kidneys and testes) were assessed by carefully dissecting each organ from sacrificed animal into $10 \%$ formal saline contained in a Petri dish. The isolated organs were dried with cotton wool and weighed on a sensitive balance. Each weighed organ was standardized for $100 \mathrm{~g}$ body weight of each rat.

Effects on blood glucose and lipid: The fasting blood glucose was determined in blood plasma by glucose oxidase method (Trinder, 1969). Total cholesterol, high density lipoprotein-cholesterol (HDLcholesterol) and triglyceride using blood serum, were estimated by modified enzymatic method from Sigma Diagnostics (Wassan et al., 2001).

Biochemical parameters: The effect of the extract on certain biochemical parameters were examined and compared with those of the control group. The blood samples collected with heparinized bottles were centrifuged at $5000 \mathrm{rpm}$ for 10 minutes to obtain clear plasma for the following investigations: Total, direct and indirect bilirubin were determined using Jandrassik and Grof technique (Koch and Doumas, 1982); alanine amino transferase (ALT) and aspatate amino transferase (AST) were measured by using enzymatic method (Horder and Sampson, 1991); alkaline phosphatase (ALP) was analyzed according to the method of Kind (1954); total protein (TP) concentration was determined by Biuret method (Doumas, 1975); albumin was determined based on its reaction with bromocresol green (Binding method) (Spencer and Price, 1971); urea was determined according to Urease-Berthelot method (Weatherburn, 1967) and plasma creatinine was estimated using Jaffe reaction (Perone et al., 1992).

Haematological parameters: Diethyl ether was used to anaesthetize the animals before blood samples were collected through heart puncture into different heparinized tubes. The blood samples were analyzed for red blood cells (RBC) by haemocytometic method (Dacie and Lewis, 1984); the haemoglobin $(\mathrm{Hb})$ content was by Cyanmethaemoglobin (Drabkin) method (Dacie and Lewis, 1984); packed cell volume (PCV) was according to Ekaidem et al., (2006) while white blood 
cells (WBC) and its differentials (neutrophil, eosinophil, basophil, lymphocyte and monocyte) were as described by Dacie and Lewis (1984).

Tissue histology: The organs-liver, heart, kidney and testes- were fixed in Bouin's fluid before being processed and stained with Haematoxylin and Eosin $(\mathrm{H}$ and $\mathrm{E})$ stain.

Statistical analysis: All values were expressed as mean \pm standard error of mean and the statistical significance between treated and control groups were analyzed by means of Student's t-test. $\mathrm{P}<0.05$ was considered significant.

\section{RESULTS}

The acute toxicity study showed that animals fed with the leaves extract by gastric gavages tolerated up to $11 \mathrm{~g} / \mathrm{kg}$ body weight. The intra-peritoneal (IP) administration produced dose dependent mortality with median acute toxicity $\left(\mathrm{LD}_{50}\right)$ of approximately $1445.4 \mathrm{mg} / \mathrm{kg}$.

There was significant weight gain after 120 days of extract treatment that was dose dependent. The percentage increase in the weight of the animals compared to the normal is shown in Fig.1. The result of the effect of the extract on the harvested organs weight is presented in Table 2 which showed weight gain that was comparably higher than the control. The blood glucose and cholesterol levels decreased respectively in dose dependent manner. Triglycerides exhibited fluctuation while HDL-cholesterol increased with dose. The summary of results of biochemical parameters is presented in Table 5. Generally, there were insignificant changes $(p \geq 0.05)$ compared to the control with the exception of albumin and urea that recorded marked differences $(p<0.05)$. AST and creatinine showed fluctuation of values with Table 1: Acute toxicity determination of SJ leaf ethanol extract (intraperitoneal route)

\begin{tabular}{|c|c|c|c|c|c|c|}
\hline GROUP & Dose & Log Dose & 24h Mortality & $\%$ Mortality & Probit & $\begin{array}{l}\text { Probit } \\
\text { (Approx) }\end{array}$ \\
\hline 1 & $500 \mathrm{mg}$ & 2.70 & ${ }^{1} / 8$ & 12.5 & 3.8497 & 3.8 \\
\hline 2 & $1000 \mathrm{mg}$ & 3.00 & ${ }^{2} / 8$ & 25.0 & 4.3255 & 4.3 \\
\hline 3 & $2000 \mathrm{mg}$ & 3.30 & $4 / 8$ & 50.0 & 5.000 & 5.0 \\
\hline 4 & $4000 \mathrm{mg}$ & 3.60 & $7 / 8$ & 87.5 & 6.1503 & 6.2 \\
\hline
\end{tabular}

Table 2: Data on the organ weight $(100 \mathrm{~g}$ body weight) in rats after sub-chronic treatment with SJ leaf extract

\begin{tabular}{lccccc}
\hline Treatment & \multicolumn{5}{c}{ Mean organ weight per $100 \mathrm{~g}$ body weight } \\
& Heart & Lung & Liver & Kidney & Testes \\
\hline Control & $0.4 \pm 0.7$ & $1.7 \pm 0.3$ & $7.8 \pm 0.7$ & $1.2 \pm 0.1$ & $3.3 \pm 0.2$ \\
$50 \mathrm{mg} / \mathrm{kg}$ & $0.4 \pm 0.1$ & $2.1 \pm 0.2$ & $9.2 \pm 0.9$ & $1.5 \pm 0.2$ & $3.9 \pm 0.2$ \\
$100 \mathrm{mg} / \mathrm{kg}$ & $0.4 \pm 0.3$ & $2.1 \pm 0.2$ & $9.4 \pm 0.6$ & $1.6 \pm 0.9$ & $4.1 \pm 0.2$ \\
$200 \mathrm{mg} / \mathrm{kg}$ & $0.6 \pm 1.1$ & $2.2 \pm 0.1$ & $9.5 \pm 0.9$ & $1.7 \pm 0.1$ & $4.3 \pm 0.7$ \\
\hline
\end{tabular}

increased concentration of the extract. Table 3 showed the effect of the extract on haematological parameters of the animals. Administration of the extract led to significant dose dependent increase $(p<0.05)$ in RBC, Hb and PCV levels compared to the control. On the other hand, MCV, MCH, MCHC and WBC did not vary markedly. Similarly, WBC differentials did not record appreciable difference with respect to the control.

Histological studies: Figures 2-9 showed the histological studies of some vital organs of the animals treated with leaf extract of SJ. The hepatic tissue of the control group (Fig, 2) showed the portal trait. The hepatocytes interspaced by the hepatic sinusoids formed radial arrangement. In the animals (Fig. 3) treated with $200 \mathrm{mg} / \mathrm{kg}$ bwt, hepatic tissue showed no pathological changes, the dark spots observed could however be mere artifacts.

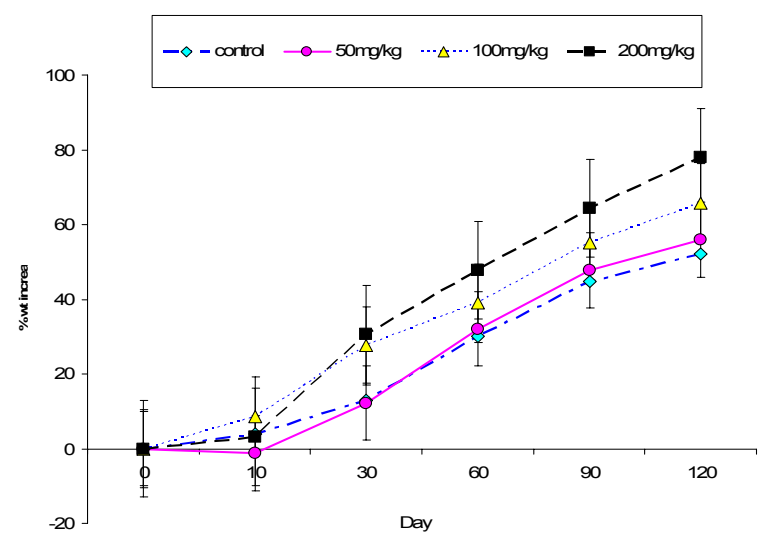

Fig.1 Percentage increase in the weight of the control and treated animals in sub chronic study

\footnotetext{
Mean \pm SEM, $(n=5){ }^{*} p<0.05$ vs. control group.
} 
Agric. Biol. J. N. Am., 2010, 1(3): 265-272

Table 3: Haematological values of rats in sub- chronic treatment with SJ leaf ethanol extract

\begin{tabular}{llllcccc}
\hline Treatment & $\mathrm{RBC}\left(\mathrm{x} 10^{6}\right)$ & $\mathrm{Hb}(\mathrm{g} / \mathrm{dl})$ & $\mathrm{PCV}(\%)$ & $\mathrm{WBC}\left(\mathrm{x} 10^{3}\right)$ & $\mathrm{MCV}(\mathrm{fl})$ & $\mathrm{MCH}(\%)$ & $\mathrm{MCHC}(\%)$ \\
\hline Control & $4.5 \pm 0.2$ & $13.3 \pm 0.3$ & $44.0 \pm 1.8$ & $4.2 \pm 0.5$ & $8.4 \pm 1.4$ & $3.0 \pm 0.1$ & $30.4 \pm 0.8$ \\
$50 \mathrm{mg} / \mathrm{kg}$ & $6.0 \pm 0.3^{*}$ & $15.4 \pm 0.8^{*}$ & $51.2 \pm 0.4^{*}$ & $4.1 \pm 0.4$ & $8.3 \pm 0.5$ & $2.7 \pm 0.3$ & $30.3 \pm 0.1$ \\
$100 \mathrm{mg} / \mathrm{kg}$ & $6.0 \pm 0.9^{*}$ & $15.9 \pm 0.4^{*}$ & $52.8 \pm 0.9^{*}$ & $4.3 \pm 0.1$ & $8.4 \pm 0.1$ & $2.6 \pm 0.1$ & $30.3 \pm 0.8$ \\
$200 \mathrm{mg} / \mathrm{kg}$ & $6.3 \pm 0.9^{*}$ & $15.9 \pm 0.3^{*}$ & $53.4 \pm 1.0^{*}$ & $4.3 \pm 0.8$ & $8.3 \pm 0.1$ & $2.5 \pm 0.2$ & $28.7 \pm 1.9$
\end{tabular}

Mean \pm SEM, $(n=5){ }^{*} p<0.05$ vs. control group.

Table 4: Quantitative data on WBC differentials in rats after sub-chronic treatment with SJ leaf extract

\begin{tabular}{llcccc}
\hline Treatment & Neutrophil \% & Lymphocyte $\%$ & Eosinophil \% & Basophil \% & Monocyte \% \\
\hline Control & $54.0 \pm 4.0$ & $29.8 \pm 4.8$ & $12.5 \pm 4.4$ & $1.8 \pm 0.9$ & $8.3 \pm 3.1$ \\
$50 \mathrm{mg} / \mathrm{kg}$ & $50.8 \pm 4.4$ & $34.8 \pm 4.0$ & $8.5 \pm 2.6$ & $1.5 \pm 0.7$ & $9.8 \pm 2.8$ \\
$100 \mathrm{mg} / \mathrm{kg}$ & $50.2 \pm 4.2$ & $36.5 \pm 4.3$ & $10.5 \pm 1.0$ & $1.0 \pm 0.4$ & $9.8 \pm 3.1$ \\
$200 \mathrm{mg} / \mathrm{kg}$ & $47.5 \pm 2.0$ & $39.3 \pm 3.8$ & $10.5 \pm 2.2$ & $1.5 \pm 0.6$ & $11.5 \pm 2.2$ \\
\hline
\end{tabular}

Mean \pm SEM, $(n=5){ }^{*} p<0.05$ vs. control group.

Table 5: Blood chemistry values of rats in sub- chronic treatment with SJ leaf ethanol extract

\begin{tabular}{lcccc}
\hline & & \multicolumn{2}{c}{ Treatment $(\mathrm{mg} / \mathrm{kg})$} & \\
Parameter & Control & 50 & 100 & $53.7 \pm 1.8$ \\
\hline Total protein $(\mathrm{mg} / \mathrm{dl})$ & $55.7 \pm 0.8$ & $54.1 \pm 3.4$ & $54.2 \pm 2.5$ & $46.4 \pm 3.4^{*}$ \\
Albumin $(\mathrm{mg} / \mathrm{dl})$ & $36.1 \pm 1.5$ & $40.1 \pm 2.1$ & $44.5 \pm 1.1^{*}$ & $1.7 \pm 0.9$ \\
Total bilirubin $(\mathrm{mg} / \mathrm{dl})$ & $1.4 \pm 0.1$ & $1.5 \pm 0.6$ & $1.8 \pm 0.1$ & $0.2 \pm 0.1$ \\
Direct bilirubin $(\mathrm{mg} / \mathrm{dl})$ & $0.1 \pm 0.0$ & $0.2 \pm 0.1$ & $0.1 \pm 0.0$ & $1.8 \pm 0.1$ \\
Indirect bilirubin $(\mathrm{mg} / \mathrm{dl})$ & $1.3 \pm 0.8$ & $1.7 \pm 02$ & $1.7 \pm 0.1$ & $54.9 \pm 10.4$ \\
AST $(\mathrm{i} \mu / \mathrm{L})$ & $52.5 \pm 14.8$ & $56.5 \pm 5.6$ & $59.8 \pm 11.2$ & $18.7 \pm 2.4$ \\
ALT $(\mathrm{i} \mu / \mathrm{L})$ & $15.2 \pm 2.6$ & $17.1 \pm 3.3$ & $18.0 \pm 1.8$ & $142.6 \pm 3.5$ \\
Alkaline phosphatase $(\mathrm{i} \mu / \mathrm{L})$ & $149.5 \pm 2.4$ & $138.0 \pm 2.3$ & $138.2 \pm 5.0$ & $73.8 .0 \pm 6.7^{*}$ \\
Urea $(\mathrm{mg} / \mathrm{dl})$ & $90.5 \pm 4.1$ & $73.4 \pm 3.9^{*}$ & $71.4 \pm 2.7^{*}$ & $1.5 \pm 0.1$ \\
Creatinine $(\mathrm{mg} / \mathrm{dl})$ & $1.3 \pm 0.1$ & $1.4 \pm 1.2$ & $1.7 \pm 0.1$ & $79.3 \pm 9.0$ \\
Glucose $(\mathrm{mg} / \mathrm{dl})$ & $86.0 \pm 4.8$ & $84.8 \pm 2.1$ & $84.2 \pm 6.1$ & $68.6 \pm 3.9$ \\
Total cholesterol $(\mathrm{mg} / \mathrm{dl})$ & $78.3 \pm 3.3$ & $75.2 \pm 4.8$ & $72.0 \pm 2.1$ & $45.3 \pm 8.8$ \\
Triglycerides $(\mathrm{mg} / \mathrm{dl})$ & $50.7 \pm 6.1$ & $54.5 \pm 9.3$ & $50.3 \pm 3.9$ & $27.3 \pm 4.8$ \\
HDL-cholesterol $(\mathrm{mg} / \mathrm{dl})$ & $24.4 \pm 4.1$ & $24.3 \pm 5.2$ & $24.8 \pm 2.3$ &
\end{tabular}

Mean \pm SEM, $(n=5){ }^{*} p<0.05$ vs. control group.

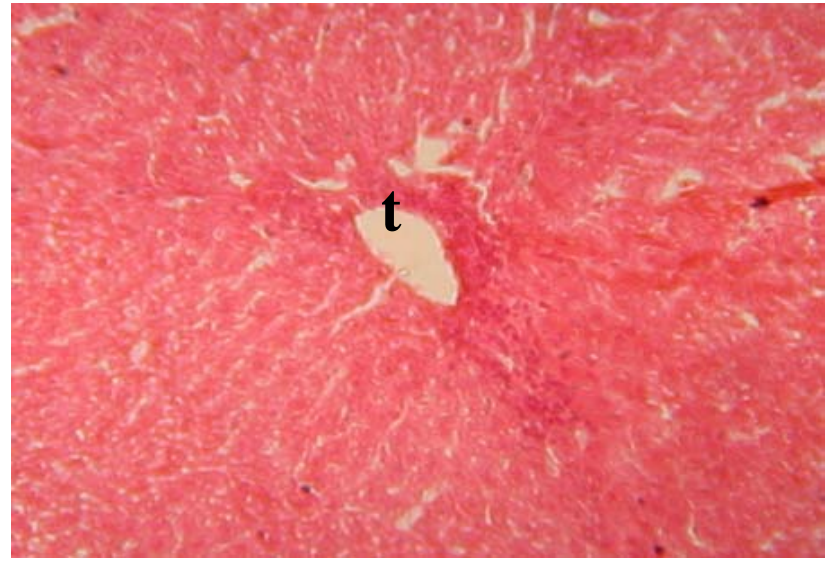

Fig. 2: The photomicrograph of hepatic tissue (control group) showing the portal tracts $(t)$. (H and E stain) mag. $x 200$.

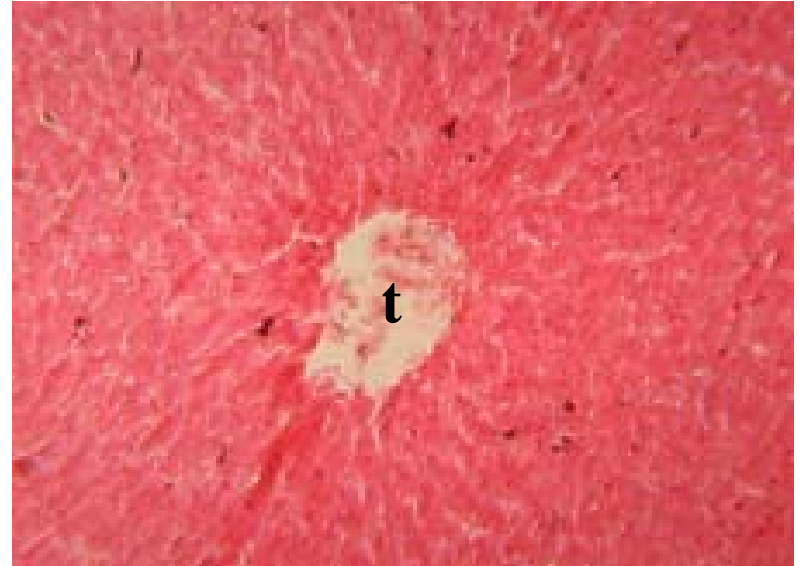

Fig. 3: The histology of the cross section of hepatic tissue treated with $200 \mathrm{mg} / \mathrm{kg}$ of the leaf extract. (H and E stain) mag. X200. 
Agric. Biol. J. N. Am., 2010, 1(3): 265-272

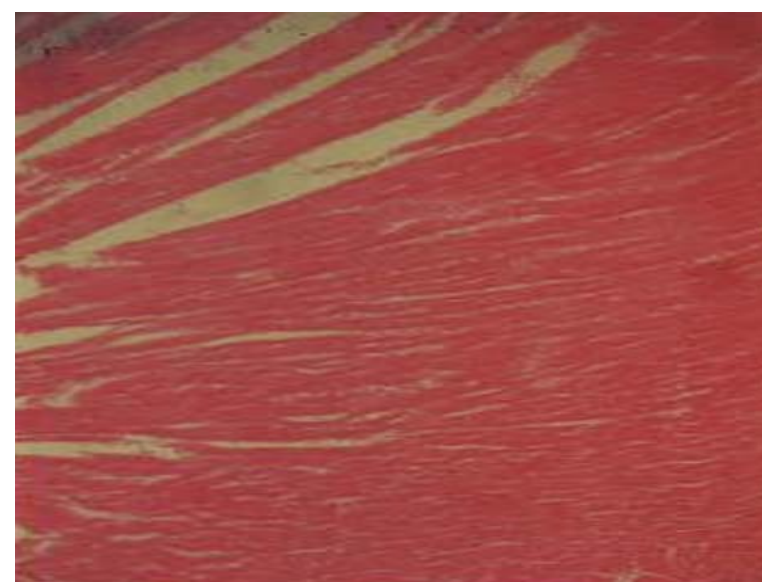

Fig. 4: The photomicrograph of cardiac muscle (control group) forming branched network. (H and E stain) mag. x100.

Fig. 6: The histology of a cross section of renal tissue of the control group showing renal corpuscles and Bowman's spaces. (H and E stain) mag. x100.

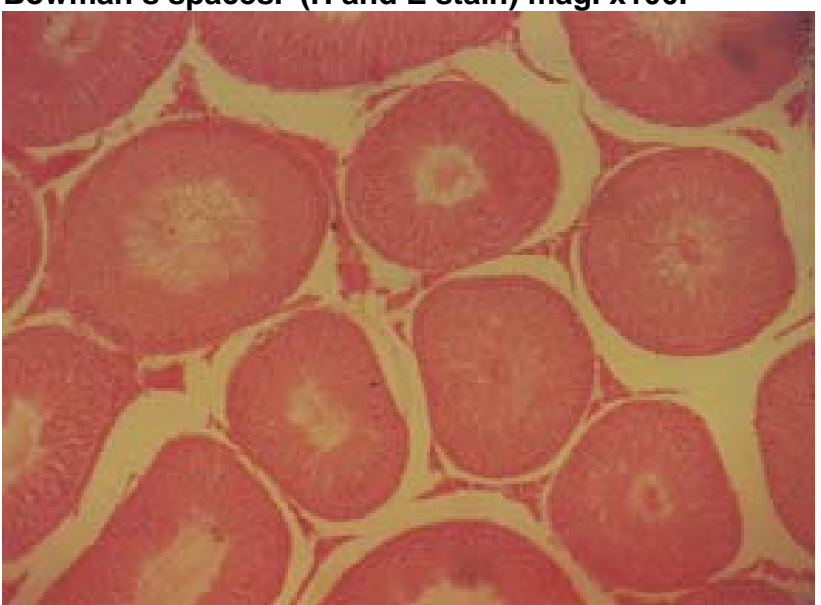

Fig. 8: The cross section of testes of the control group showing seminiferous tubules interspaced by thick interstitium (H and E stain) mag. x100.

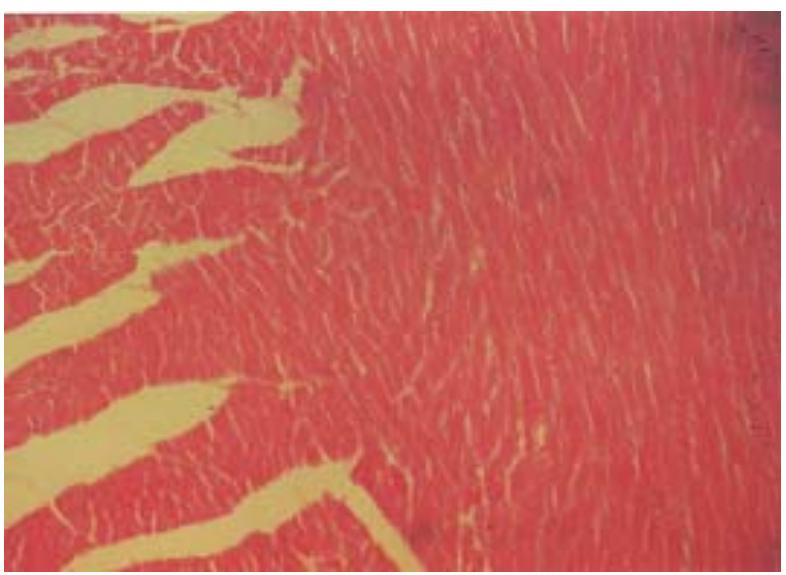

Fig. 5: The cross section of the cardiac muscle of the group treated with $200 \mathrm{mg} / \mathrm{kg}$ of the extract. No abnormality was observed. (H and E stain) mag. x100.

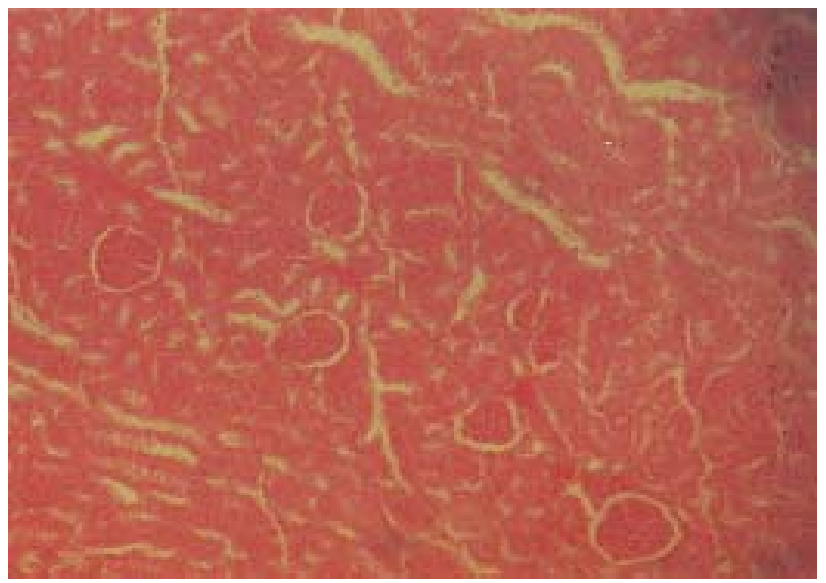

Fig. 7: The cross section of renal tissue of the group treated with $200 \mathrm{mg} / \mathrm{kg}$ of the extract. No renal abnormality was observed. (H and E stain) mag. x100.

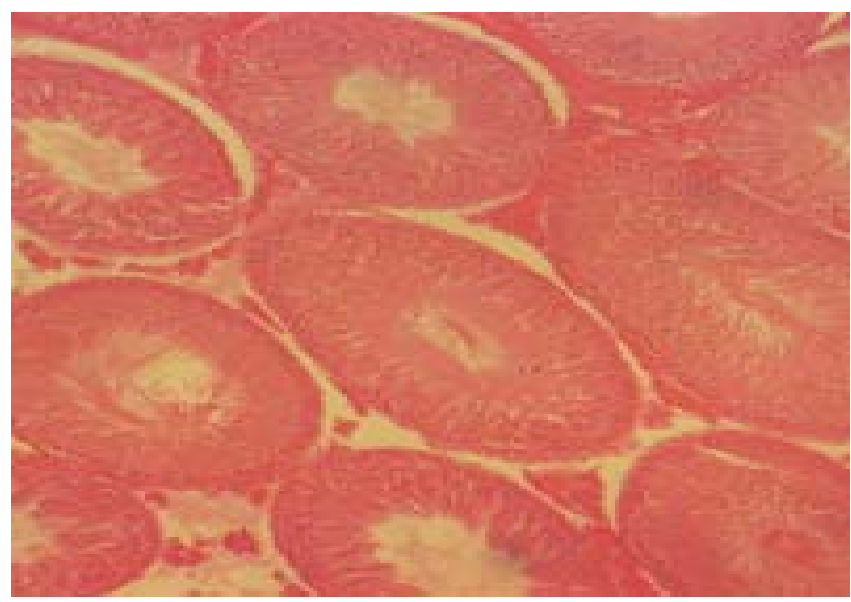

Fig. 9: The cross section of seminiferous tubules of testis treated with $200 \mathrm{mg} / \mathrm{kg}$ of the extract showing thick germinal epithelium (H and E stain) mag. x100. 
The cardiac muscle of the control group (Fig. 4) showed the muscle fibres forming a branched network. In the treated group (Fig. 5), no lesion was observed.

The kidney of the control group showed cortical area of renal tissue with glomerular apparatus (Fig. 6) forming a rounded mass and separated from the surrounding structures by Bowman's space. In Fig 7, animals treated with $200 \mathrm{mg} / \mathrm{kg}$ bwt showed no structural changes.

Fig. 8 (control group) showed normal testis, the seminiferous tubules cut at different planes showed distinct boundary separated by thick interstitial spaces. The wall of the seminiferous tubules showed thick germinal epithelium; close to the base of the epithelium were the differentiating spermatogonia while spermatocytes formed a cluster in the lumina. In the treated animals (Fig. 9), no structural changes were observed.

\section{DISCUSSION}

The result obtained from the acute toxicity study showed that the ethanol leaf extract of SJ demonstrated high safety margin since the animals tolerated up to $11 \mathrm{~g} / \mathrm{kg}$ body weight of the extract orally. Following IP administration, the median acute toxicity $\left(\mathrm{LD}_{50}\right)$ of approximately $1445.4 \mathrm{mg} / \mathrm{kg}$ was recorded. In toxicity rating by joint $\mathrm{FAO} / \mathrm{WHO}$ Expert Committee on Food Additives (WHO, 1966), if at $2 \mathrm{~g} / \mathrm{kg}$ oral dose no death occurred, it is sufficient to assume the substance to be non toxic. The high safety margin through oral route justified its therapeutic use by the traditional healers.

In chronic study, when the extract was administered daily to the animals for a period of 120 days, no mortality or morbidity was observed. There was significant weight gain in both the treated and the control groups with percentage weight gain depicted in Fig. 1. The gross examination of internal organs revealed no detectable inflammation while the weight of the animals treated with the extract was comparably higher than the control. According to reports, reduction in body and internal organ weights are considered sensitive indices of toxicity after exposure to toxic substance (Raza et al., 2002; Teo et al., 2002; Thanabhorn et al., 2006).

The decrease in blood glucose and total cholesterol levels in the treated animals demonstrated the presence of hypoglycaemic and hypolipidemic agents respectively. The presence of hypolipidemic agent is indicative of the extract potential beneficial effect against cardiovascular risk factor (Zhou et al., 2006).
In a toxic environment, blood level of AST and ALT are known to significantly increase (Adam, 1998; Crook, 2006). These two classical enzymes are reliable indices of liver toxicity (Hayes, 1989). Since in this study the enzymes showed no appreciable increase in the treated animals, it implied that the extract has no hepato-toxic effect. This was confirmed by the histological study in which tissue morphology showed no changes.

The renal function profile, serum creatinine and urea levels, was not significantly altered compared to the control. These compounds which are non-protein nitrogenous substances are said to be end products of protein metabolism that must be removed continually (Guyton, 1981). The insignificant changes in creatinine and urea levels suggested that the activity of protein metabolism was maintained within the normal range due to relatively non-toxic effect of the extract.

In haematological evaluation, marked increase in $\mathrm{RBC}, \mathrm{PCV}$ and $\mathrm{Hb}$ were observed compared to the control while mean corpuscular volume (MCV), mean corpuscular haemoglobin (MCH) and mean corpuscular haemoglobin concentration (MCHC) showed no significant variation. The increase in RBC was an indication of changes in the rate of the RBCs production. In this context, the possibility that the extract does have the potential to stimulate erythropoietin release in the kidney was likely. This is similar to results obtained with some other plants (Polenakovic and Sikole, 1996; Sanchez-Elsner et al., 2004).

The importance of $\mathrm{MCH}, \mathrm{MCV}$ and $\mathrm{MCHC}$ in anaemia diagnosis in most animals has been highlighted (Cole, 1986). From this result, the extract did not significantly alter the calculated RBC indices which were indicative of its minimal effect on the size of $\mathrm{RBC}$ and in $\mathrm{Hb}$ weight per RBC. This implies that ethanol leaf extract of $S J$ does not possess the potential to induce anaemia. Inflammatory process is characterized by the involvement of multiple inflammatory cells of the WBC (Kytridis and Manetas, 2006). WBC and indices relating to it such as lymphocytes usually show increase in activity in response to toxic environment (Robins, 1974). In this study, WBC was not significantly altered while lymphocytes, the main effectors cells of the immune system (McKnight et al., 1999) showed marginal increase thus suggesting that the extract only exerted minimal challenge on the immune system of the animals. 
The findings from this investigation provided more information on the therapeutic safety of this herbal drug. The leaf of SJ was observed not to exert hepato-toxic effect that would cause the liver to compromise its function. Furthermore, the indices pertaining to renal function showed no abnormality. On the other hand, the significant increase in RBC, $\mathrm{Hb}$ and PCV in the treated animals demonstrated the hematinic potential of the extract.

\section{ACKNOWLEDGMENT}

The authors wish to sincerely thank Chief Adeyemi Adebambo, who assisted with the collection of the plant.

\section{REFERENCES}

Adam, S. E. I. (1998). Toxic effects of Francoeuria crispa in rats. Phytotherapy research. 2: 476-479.

Chan, K. (2003). Some aspect of toxic contaminants in herbal remedies. A review. Chemosphere. 52: 1361 1371.

Coles, E. H. (1986). Veterinary clinical pathology. W. B Saunders, Philadelphia, USA, 10-42.

Crook, M. A. (2006). Clinical Chemistry and Metabolic Medicine. $7^{\text {th }}$ Edition. Hodder Arnold, London: 426.

Dalziel, J. M. (1955). In: The useful plants of West Africa. Crown agents for overseas governments and administration, London. 15.

Dacie, J. C and Lewis, S. M. (1984). Practical haematology $5^{\text {th }}$ Edn, Churchill Livingstone, London.

Ekaidem, I. S., Akpanabiatu, M. I., Uboh, F. E and Eka, O. U. (2006). Vitamin b12 supplementation: effects on some biochemical and haematological indices of rats on phenytoin administration. Biochem 18, 1: 31- 37

Doumas, B. T. (1975). Standards for total serum protein assays-a collaboration study: Clinical chemistery. 21 : 1159-1166.

Elvin-Lewis, M. (2001). Should we be concerned about herbal remedies? J. Ethnopharmacol. 75: 141-164.

Farnsworth, N. R and Soejarto, D. D. (1985). Potential consequence of plant extinction in the United States on the current and future availability of prescription drugs. Econ Bot. 39: 231-240.

Guyton, A. C. (1981). Textbook of medical pathology, $6^{\text {th }}$ ed. W. B. Saunders Company, Philadelphia, USA. 463-474.

Hayes, M. L. (1989). Guidelines for acute oral toxicity testing. In: Principles and methods of toxicology. $2^{\text {nd }}$ ed. $143-152$.

Horn, H. J. (1956). Simplified $\mathrm{LD}_{50}$ (or $\mathrm{ED}_{50}$ ) calculations. Biometrics. 12, 312-322.
Horder, M. and Sampson, E. J. (1991). Approved IFCC recommendation on methods for the measurement of catalytic concentration of enzymes Part7: IFCC method for creatinine Kinase (ATP: Creatinine Nphosphotransferase, EC. 2. 7. 3. 2) Eur. J Clin. Chem. Clin. Biochem. 29:435-456.

Kind, A. (1954). Eisenresorptionsiversuch und eisenbindunge- kapazitat im serum bei der diagnose des eisenmangels, Helvet. Med. Acta. 21: 402- 407.

Koch, T. R and Doumas, B. T. (1982). Bilirubin, total and conjugated, modified Jendrassik Grot method. In selected methods of clinical chemistry vol. 9, edited by W Faulkner and S Meites Washington DC, American Ass. for Clin. Chem. 113.

Kytridis, V.P and Manetas, Y. (2006). Maesophyll versus epidermal anthocyanins as potential in vivo antioxidants: evidence linking the putative antioxidant role to the proximity of oxy-radical source. J Exp Bot. 57: 2203-2210.

Iwu, M. M. (1993). Handbook of African medicinal plants. CRC Press Inc. 239.

Mc Knight, D. C., Mills, R. G., Bray, J. J and Crag, P. A. (1999). Human Physiology. $4^{\text {th }}$ Edition, Churchill Livingstone, 290-294.

Moody, J. O., Roberts, V. A., Connolly, J. D and Houghton, P. J. (2006). Anti- inflammatory activities of the methanol extracts and an isolated furanoditerpene constituent of Sphenocentrum jollyanum Pierre (Menispermaceae). J Ethnopharmacol. 104: 87-91.

Nia, R., Paper, D. H., Essien, E. E., Iyadi, K. C., Bassey, A. I. L., Antai, A. B and Franz, G. (2004). Evaluation of the anti-oxidant and anti-angiogenic effects of Sphenocentrum jollyanum Pierre, African J. Biomed Res. 7:129-132.

Odugbemi, T. (2006). Medicinal plants by species names: Outlines and pictures of medicinal plants from Nigeria. Lagos University press.

Perone, R. D., Madias, N. E and Levey, A. S. (1992). Serum creatinine as an index of renal function: New insight into old concepts. Clin Chem. 38: 1933-1953.

Polenakovic, M and Sikole, (1996). Is erythropoietin a survival factor for red blood cells? J Am Soc Nephrol. 7: 1178-1182.

Raza, M., Al-Shabanah, O. A., El-Hadiyah, T. M and AlMajed, A. A., (2002). Effect of prolonged vigabatrin treatment on hematological and biochemical parameters in plasma, liver and kidney of Swiss albino mice. Scientia Pharmaceutica. 70: 135-145.

Robins, S. L. (1974). Lymph nodes and spleen: Pathologic basis of disease. WB Saunders Co., Philadelphia, 1050 . 
Said, O., Khalil, K., Fulder, S and Azaizeh, H (2002). Ethnobotanical survey of medicinal herbs of the Middle Eastern region. J. Ethnopharmacol. 83: 251-265.

Sanchez-Elsner, T., Ramirez, J. R., Rodriguez-Sanz, F., Varela, E., Bernabew, C and Botella, L. M. (2004). A cross talk between hypoxia and TGF-beta orchestrates erythropoietin gene regulation through SPI and SMADS. J Mol Biol. 36: 9-24.

Spencer, K and Price, C. P. (1971). Determination of serum albumin using Bromoscresol techniques. Annals Clin Biochem. 14: 105-115.

Teo, S., Stirling, D., Thomas, S., Hoberman, A., Kiorpes, A and Khetani, V. (2002). A 90 day oral gavage toxicity study of D-methylphenidate and D, L-methylphenidate in Sprague dawley rats. Toxicology. 179: 183-190.

Thanabhorn, S., Jenjoy, K., Thamaree, S., Ingkaninan, K and Panthong, A. (2006). Acute and subacute toxicity study of the ethanol extract from Lonicera japonica Thunb. J. Ethnopharmacol. 107: 370-373.
Trinder, P. (1969). Determination of glucose in blood using glucose oxidase with an alternative oxygen acceptor. Annals Clin Biochem. 6: 24.

Wassan, K. M., Najafi, S., Wong, J and Kwong, M. (2001). Assessing plasma lipid levels, body weight, and hepatic and renal toxicity following chronic oral administration of a water soluble phytostanol compound FM-VP4, to gerbils. J. Pharmaceutical Sci. 4, 3: $228-234$

Weatherburn, M. W. (1967). Phenol-hypochlorite reaction for determination of ammonia. Annal. Chem. 39: 971974.

WHO, (1966). Specifications for identity and purity and toxicological evaluation of food colours. WHO/Food Add/66.25 Geneva WHO.

Zhou, W, Chai, H, Lin, H. P., Lumsden, B. A., Yao, Q and Chen, C. (2006). Clinical Use and Molecular Mechanisms of Action of Extract of Ginkgo biloba Leaves in Cardiovascular Diseases. Cardiovascular Drug Review. 22: 309-319. 